\title{
Schade in de virtuele wereld: de casus virtuele grooming $^{*}$
}

Jeroen ten Voorde

\section{$1 \quad$ Inleiding}

De laatste tijd wordt betrekkelijk veel aandacht besteed aan seksuele gedragingen met virtuele personen. Een virtuele persoon kan een grafisch object zijn, veelal gelijkend op een mens, of een schuilnaam die zich op internet tijdens gesprekken manifesteert. ${ }^{1}$ Dergelijke gesprekken vinden bijvoorbeeld plaats in chatrooms op internet. De ene gesprekspartner verkeert daarbij in de veronderstelling met een niet-virtuele persoon te spreken. Deze gesprekken kunnen (mede) een seksuele strekking hebben en/of zijn bedoeld die persoon over te halen om elkaar buiten het internet te ontmoeten teneinde (met elkaar) seksuele gedragingen te verrichten.

Indien de virtuele persoon een minderjarige voorstelt, komt de vraag op of dergelijke gedragingen strafbaar moeten worden gesteld. Het voeren van gesprekken met een niet-bestaande minderjarige waarbij een ontmoeting wordt voorgesteld tijdens welke het doel is de minderjarige seksueel te misbruiken, is naar Nederlands recht op dit moment niet apart strafbaar gesteld. Strafbaar is wel het voeren van gesprekken met een 16-minner waarbij een ontmoeting wordt voorgesteld, met als doel om tijdens de ontmoeting die persoon seksueel te misbruiken of daarvan kinderpornografische afbeeldingen te maken, en enige handeling te verrichten om die ontmoeting te verwezenlijken (art. 248e Sr). Deze strafbaarstelling wordt online grooming en soms ook cyberkinderlokken genoemd. Omdat het in deze bijdrage alleen gaat om online grooming, laat ik het adjectief online hierna weg.

De strafbaarstelling wordt uitgebreid zodat ook grooming van een virtuele persoon onder het bereik van de strafwet komt te vallen. ${ }^{2}$ Daarbij wordt in de literatuur opgemerkt dat strafbaarstelling van deze vorm van grooming onder meer ethische vragen oproept. ${ }^{3}$ In deze bijdrage staat de vraag centraal of strafbaarstelling van virtuele grooming valt te rechtvaardigen. Voor het antwoord op deze vraag wordt allereerst bezien welke rechtvaardiging de wetgever zelf heeft geformuleerd. We zullen zien dat deze verwijst naar het schadebeginsel. De door de

* De auteur bedankt de reviewers voor hun nuttige commentaar op een eerdere versie van deze bijdrage.

1 Vgl. Litska Strikwerda, 'Virtual Acts, Real Crimes? A Legal-Philosophical Analysis of Virtual Cybercrime' (diss. Universiteit Twente, 2014): 24.

2 Kamerstukken I 2016/17, 34372, A.

3 Bart W. Schermer e.a., Legal Aspects of Sweetie 2.0 (Leiden/Tilburg: Center for Law and Digital Technologies/Tilburg Institute for Law, Technology and Society, 2016), 84. 
wetgever geformuleerde rechtvaardiging wordt vervolgens getoetst aan een in deze bijdrage geformuleerde invulling van het schadebeginsel.

\section{Virtuele grooming}

\section{De huidige strafbaarstelling van grooming}

De strafbaarstelling van grooming werd ingevoerd in het kader van de implementatie van artikel 23 van het op Lanzarote gesloten Verdrag inzake de bescherming van kinderen tegen seksuele uitbuiting en seksueel misbruik. ${ }^{4}$ Aan dit verdrag lag een aantal redenen ten grondslag, onder meer dat seksuele uitbuiting en seksueel misbruik 'zeer schadelijke gevolgen hebben voor de gezondheid van kinderen en hun psychosociale ontwikkeling' en dat deze gedragingen 'verontrustende proporties' hebben aangenomen, waartegen kinderen moeten worden beschermd. Dit levert geen specifieke rechtvaardiging van strafbaarstelling van grooming op. Die vinden we wel in Richtlijn 2011/93/EU. ${ }^{5}$ In overweging 19 van de preambule van deze richtlijn staat dat het benaderen van kinderen voor seksuele doeleinden een 'bedreiging' voor kinderen vormt. Dit wijst erop dat grooming zelf niet als seksueel misbruik wordt beschouwd, maar zich in de voorfase daarvan afspeelt.

De wetgever heeft dit uitgangspunt op het eerste gezicht overgenomen. Grooming wordt omschreven als een gedraging die tot doel heeft kinderen seksueel te misbruiken. Dat wekt de indruk dat grooming zelf niet tot het misbruik wordt gerekend. ${ }^{6}$ De gedragingen die grooming opleveren worden in de parlementaire stukken voorbereidingshandelingen genoemd. ${ }^{7}$ Daaruit volgt dat bij grooming van het toebrengen van schade, oftewel het daadwerkelijk seksueel misbruik van kinderen of maken van kinderpornografie, geen sprake is. Verschillende Nederlandse auteurs nemen aan dat grooming wel een gevaar voor schade oplevert. ${ }^{8}$

Erg duidelijk is de wetgever in het omschrijven van grooming niet. Tegenwoordig omschrijft hij grooming namelijk niet alleen als voorbereidingsdelict, maar ook als een 'vanuit maatschappelijk oogpunt bezien' zeer schadelijk verschijnsel. ${ }^{9}$ De schade bestaat erin dat met behulp van nieuwe communicatiemiddelen kinderen worden benaderd en verleid met bijvoorbeeld seksueel misbruik tot doel. Wellicht

$4 \quad$ Verdrag van 25 oktober 2007, Trb. 58.

5 Voluit: Richtlijn 2011/93/EU van het Europees Parlement en de Raad van 13 december 2011 ter bestrijding van seksueel misbruik en seksuele uitbuiting van kinderen en kinderpornografie, en ter vervanging van Kaderbesluit 2004/68/JBZ, PbEU 2011, L 335/1.

6 Kamerstukken II 2008/09, 31810, 3, 6.

7 Kamerstukken II 2008/09, 31810, 3, 9; Kamerstukken II 2008/09, 31810, 7, 8. Zie ook Committee of the Parties to the Council of Europe Convention on the protection of children against sexual exploitation and sexual abuse (hierna: Lanzarote Committee), Opinion on Article 23 of the Lanzarote Convention and its explanatory note (Straatsburg: Raad van Europa, 2015).

8 Zie Jeroen ten Voorde, 'Strafbaarstelling van nieuwe vormen van ongewenste seksuele gedragingen in Nederlandse zedenwetgeving,' in Vereniging voor de vergelijkende studie van het recht van België en Nederland. Preadviezen 2016, red. Daan Asser (Den Haag: Boom juridisch, 2016), 238-39.

9 Kamerstukken II 2015/16, 34372, 3, 68. Vgl. A.R. Lodder, 'Grooming: over meerderjarigen die internet en jeugdigen misbruiken,' Tijdschrift voor internetrecht (2015): 56-62. 
gingen ook de opstellers van het verdrag hiervan uit waar zij in algemene zin wijzen op de zeer schadelijke gevolgen voor kinderen van de gedragingen, waaronder grooming, die op grond van het Verdrag van Lanzarote strafbaar moeten worden gesteld. Wordt misbruik van digitale communicatiemiddelen beschouwd als het toebrengen van schade? Dat lijkt ondanks het voorgaande niet de bedoeling van de oorspronkelijke opstellers van de strafbaarstelling van grooming. ${ }^{10}$ De communicatie is niet als zodanig strafbaar; het gaat om het gebruiken van digitale communicatiemiddelen teneinde een ontmoeting met een minderjarige te realiseren tijdens welke bijvoorbeeld het seksueel misbruik zou moeten plaatsvinden. Het voorkomen van schade vormt al met al de rechtvaardiging van de huidige strafbaarstelling van grooming.

\section{De nieuwe strafbaarstelling}

De strafbaarstelling van grooming wordt in een bij de Eerste Kamer aanhangig wetsvoorstel uitgebreid naar grooming van een persoon die in werkelijkheid niet minderjarig is, hoewel hij zich tegenover de groomer als minderjarige voordoet. Deze persoon kan bijvoorbeeld een opsporingsambtenaar zijn, hij kan ook slechts 'een virtuele creatie' zijn. De term 'virtuele creatie' verwijst naar het voor Terre des Hommes ontwikkeld in de virtuele wereld bestaand kind, genaamd Sweetie, dat op chatsites in contact trad met volwassen personen die aan Sweetie voorstellen deden van seksuele aard. Met behulp van Sweetie kon een beeld worden geschetst van de omvang van seksuele communicatie met kinderen op internet. ${ }^{11}$ De uitlokkende handelingen die men Sweetie liet verrichten, maakte bestraffing van de gedragingen van de personen die Sweetie hadden benaderd op grond van de geldende regels van het strafprocesrecht problematisch. ${ }^{12}$ In het geval er geen sprake was van uitlokking, maar Sweetie door de groomer werd benaderd, ontstond de vraag of de groomer strafbaar is. Op grond van de huidige wettelijke regeling is dat niet het geval, tenzij wordt aangenomen dat ook poging tot grooming strafbaar is. ${ }^{13}$ In het onderzoek door Schermer e.a. naar de strafbaarstelling van virtuele grooming lezen we dat wanneer de gedraging (seksueel communiceren met een virtuele minderjarige) strafbaar wordt gesteld de grondslag voor die strafbaarstelling slechts kan zijn gelegen in de wens de intentie van de dader te bestraffen om met een minderjarige seksueel te communiceren en deze in de toekomst seksueel te misbruiken. ${ }^{14}$ Met deze grondslag komt volgens de onderzoekers met de strafbaarstelling van virtuele grooming de grens van wat strafbaar mag worden gesteld in zicht.

10 Lanzerote Committee, Opinion on Article 23, aant. 14.

11 Kemal Veli Açar, 'Webcam Child Prostitution: An Exploration of Current and Futuristic Methods of Detection,' International Journal of Cyber Criminology (2017): 98-109.

12 S.F.J. Smeets, 'De "lokpuber": een mislukt experiment,' Strafblad (2013): 332-38.

13 Ten Voorde, 'Strafbaarstelling,' 245-47. Vgl. HR 4 april 2017, ECLI:NL:HR:2017:579, NJ 2017/290, m.nt. Mevis.

14 Dat misbruik kan ook digitaal plaatsvinden door het kind te dwingen of te verleiden seksuele handelingen met zichzelf te verrichten voor een webcam. Zie Lanzarote Committee, Opinion on Article 23, aant. 9. 
De term 'virtuele creatie' is bij amendement aan artikel 248e Sr toegevoegd. Dat heeft als doel de wettekst te verduidelijken, niet om deze verder uit te breiden. ${ }^{15}$ De staatssecretaris van Veiligheid en Justitie uitte geen materieelrechtelijke bezwaren tegen het amendement. ${ }^{16}$ We mogen daarom aannemen dat de rechtvaardiging van de oorspronkelijk voorgestelde wetswijziging (die vooral zag op grooming van een persoon die zich als 16-minner voordoet, zoals een opsporingsambtenaar $)^{17}$ ook op de strafbaarstelling van grooming van een virtuele creatie ziet. Bezien we die rechtvaardiging, dan blijkt dat het belang kinderen te beschermen voorop wordt gesteld. Dat belang omvat niet alleen bescherming 'tegen misbruik van een concreet kind'; het wijst ook op 'bescherming van kinderen tegen gedrag op het internet of via communicatiemiddelen dat gebruikt wordt om kinderen te verleiden tot seksuele gedragingen'. ${ }^{18}$ De uitbreiding van de strafbaarstelling van grooming wordt gerechtvaardigd met het argument dat ook 'schadelijke contacten van volwassenen en kinderen' moeten worden voorkomen. ${ }^{19}$

Aldus wordt schade niet langer beperkt tot het seksueel misbruik. Het lijkt erop dat de staatssecretaris communicatie tussen volwassenen en minderjarigen schadelijk vindt, ook zonder dat een handeling ter verwezenlijking van een ontmoeting is voorgesteld. Zo bezien is grooming een krenkingsdelict in plaats van een gevaarzettingsdelict: communicatie met een minderjarige is schadelijk. Met betrekking tot virtuele grooming wordt deze stap niet gezet. Bij virtuele grooming gaat het om het voorkomen van schadelijke communicatie en het voorstellen van een ontmoeting met om het even wie, zo lang de groomer denkt met een kind jonger dan zestien jaar te maken te hebben. Kennelijk levert virtuele grooming een gevaar voor schadelijke communicatie met onbepaalde kinderen op. Juist omdat we hier te maken hebben met onbepaalde 'echte' slachtoffers, is de vraag of een dergelijke strafbaarstelling te rechtvaardigen valt.

\section{Schade en gevaar voor schade}

\section{Schade: 'setback of interests'}

Voor het bepalen van strafbaarheid van menselijk handelen wordt in de literatuur schade geregeld als vertrekpunt genomen, niet alleen in Angelsaksische, steeds vaker ook in continentale rechtstheorie. Voor een omschrijving van schade wordt steevast de omschrijving van J.S. Mill genoemd, terwijl ook wordt verwezen naar het werk van Joel Feinberg. ${ }^{20}$ Het door Mill en Feinberg gehanteerde schadebeginsel is in de kern consequentialistisch: met schade wordt het gevolg van bepaald menselijk handelen benoemd. Dat betekent onder meer dat aanhangers van het

20 Feinberg formuleerde naast het schadebeginsel ook andere rechtvaardigingen voor strafbaarstelling. Zie Joel Feinberg, The Moral Limits of Criminal Law. 4 vols. (Oxford: Oxford University Press, 1984-1988). 
schadebeginsel zich (moeten) openstellen voor empirische informatie over de gevolgen van bepaald handelen. Tegelijkertijd is het een misvatting het schadebegrip tot empirische gegevens te verengen. Waar het om gaat is het formuleren van normatieve argumenten op basis waarvan kan worden bepaald dat een zeker gevolg het predicaat schade mag krijgen. Niet alle argumenten mogen daarbij worden gebruikt. Het schadebeginsel behoort namelijk tot de politiek filosofische stroming van het liberalisme. In die stroming staat de vrijheid van burgers voorop. De overheid, waaronder de strafwetgever is begrepen, mag in het leven van burgers ingrijpen, zij het niet te diep. Gelet op dit uitgangspunt zijn argumenten die op gespannen voet staan met het liberalisme niet te gebruiken bij het bepalen of er sprake is van schade. Dat zijn bijvoorbeeld (op communitarisme geïnspireerde) argumenten die het belang van de gemeenschap boven het belang van individuele burgers stellen.

De omschrijving van schade door Feinberg laat zien dat het hem niet enkel te doen is om het door een gedraging teweeggebrachte gevolg; Feinberg spreekt namelijk over schade in termen van een aantasting van belangen. ${ }^{21}$ Strafbaarstelling is pas aan de orde wanneer de gedraging een bepaald gevolg heeft teweeggebracht, waarbij dat gevolg kan worden uitgelegd in termen van belangen. Schade betekent een aantasting van belangen. Niet alle belangen zijn voor wetgeving relevant. Het gaat in wetgeving enkel om belangen die door het recht beschermd moeten worden. Voor het strafrecht is een nadere begrenzing nodig, omdat niet alle belangen die door het recht moeten worden beschermd, ook strafrechtelijke bescherming vereisen. Vanuit een liberaal oogpunt bezien, geldt strafrecht als ultimum remedium om belangen te beschermen door tegen een aantasting van belangen op te treden. Met het strafrecht heeft de overheid het zwaarste middel in handen om burgers te dwingen te handelen in overeenstemming met de belangen die burgers zelf hebben erkend. ${ }^{22}$ Het zwaarste middel maakt de grootste inbreuk op burgerlijke vrijheden. Vanuit een liberaal perspectief mag het zwaarste middel slechts tegen burgers worden ingezet wanneer andere middelen niet tot de gewenste bescherming van de in het geding zijnde rechtsbelangen leidt. Daaraan moet worden toegevoegd dat het strafrecht slechts mag worden ingezet als het de 'meest passende reactie' vormt op een inbreuk op rechtsbelangen; strafrecht als optimum remedium. In deze term liggen proportionaliteit en subsidiariteit besloten. Ultimum en optimum remedium lijken niet op één lijn te liggen. Hoe meer geloof in een strafbaarstelling, hoe eerder zij optimum remedium zal zijn, ook al zijn er alternatieven voorhanden. Het bereiken van evenwicht tussen ultimum en optimum remedium is gewenst; wanneer wordt gekozen voor strafbaarstelling en de daardoor te maken inbreuk op belangen van burgers aanvaardbaar wordt geacht, moet het strafrecht optimaal worden ingezet, opdat de belangen van alle

21 Joel Feinberg, The Moral Limits of Criminal Law. Vol. 1, Harm to Others (New York: Oxford University Press, 1984), 33; A.P. Simester en Andreas von Hirsch, Crimes, Harms, and Wrongs: On the Principles of Criminalisation (Oxford/Portland, OR: Hart Publishing, 2011), 36.

22 Vgl. Tatjana Hörnle, "'Rights of Others” in Criminalisation Theory,' in Liberal Criminal Theory. Essays for Andreas von Hirsch, red. A.P. Simester, Antje Du Bois-Pedain en Ulfrid Neumann (Oxford/Portland, OR: Hart Publishing, 2014), 169-85. 
burgers - daders, direct belanghebbenden en vierden (overige burgers die niet als direct belanghebbenden bij het strafbare feit kunnen worden aangemerkt) - in voldoende mate worden beschermd.

In Angelsaksische literatuur wordt aangenomen dat het schadebeginsel bestaat uit een feitelijk en een normatief onderdeel. Het feitelijke onderdeel betreft de eigenlijke schade, het gevolg dat door een bepaalde gedraging wordt teweeggebracht of het nadeel dat door een ander wordt geleden. Het normatieve onderdeel betreft het oordeel dat over deze schade wordt gegeven, de inbreuk op van tevoren onderkende rechtsbelangen die door middel van het strafrecht worden beschermd. De verwijzing naar het verbod van terugwerkende kracht herinnert aan zowel de consequentialistische als de liberale achtergrond van het schadebeginsel dat niet alleen eist dat burgers hun gedrag op wetten moeten kunnen afstemmen, maar ook dat burgers van tevoren weten welke vrijheden worden ingeperkt en waarom. In Angelsaksische literatuur wordt het tweede onderdeel van het schadebeginsel samengebracht onder de term 'wrong'. ${ }^{23}$ Deze term heeft in de continentale rechtstheorie niet echt een equivalent, behalve wellicht in het in het Duitse en Nederlandse strafrecht ontwikkelde leerstuk van de wederrechtelijkheid.

Aan dat vooral op strafrechtelijke aansprakelijkheid betrekking hebbende leerstuk kunnen eerder besproken argumenten worden opgehangen die voor strafbaarstelling relevant zijn. Wederrechtelijk is alleen dat handelen dat strijdig is met het objectieve recht. Ten eerste wijst deze omschrijving van wederrechtelijkheid op proportionaliteit van strafbaarstelling. Niet al het handelen dat belangen schaadt moet strafbaar worden gesteld; slechts wanneer die belangen zo groot zijn dat zij tot het objectieve recht kunnen worden gerekend, vallen onder het bereik van het strafrecht en rechtvaardigen strafbaarstelling. Ten tweede wijst wederrechtelijkheid op subsidiariteit. De keuze voor strafbaarstelling moet worden afgewogen tegen de mogelijkheid belangen op een andere wijze te beschermen, bijvoorbeeld via het civiele recht. De argumenten voor of tegen strafbaarstelling zijn niet onveranderlijk; de vrijheid van burgers geldt ook voor slachtoffers van delicten. Aan hun rechtsbelangen kan op enig moment veel waarde worden gehecht waardoor strafbaarstelling in beeld komt. ${ }^{24}$ Hierbij geldt dat die belangen altijd in verband moeten blijven staan met duidelijk te omschrijven handelen dat een gevolg teweegbrengt en dat soms bij de ander tot nadeel lijdt.

De proportionaliteitseis stelt voorwaarden aan de in het geding zijnde belangen. Hierbij moet worden gedacht aan belangen die betrekking hebben op het volgende. ${ }^{25}$ Voor wederrechtelijkheid is ten eerste vereist dat de belangen voor lan-

23 Simester en Von Hirsch, Crimes, Harms, and Wrongs, 19-32.

24 Vgl. Andrew Ashworth, Positive Obligations in Criminal Law (Oxford/Portland, OR: Hart Publishing, 2015), 196-211 die - anders dan Hörnle (“'Rights of Others"') - ervoor waarschuwt zich niet blind te staren op (wat ik noem) het normatieve onderdeel van schade; ook het feitelijke onderdeel van schade moet volgens hem telkens aanwezig zijn. M.i. moeten beide elementen elkaar in evenwicht houden. 
gere tijd in nadelige zin zijn geraakt. Ten tweede dienen die belangen betrekking te hebben op de kwaliteit van leven. De gedraging moet hebben geleid tot of in staat zijn om de kwaliteit van leven in nadelige zin te beïnvloeden. Ten derde bepaalt niet het slachtoffer of diens kwaliteit van leven ten nadele is beïnvloed; de in het geding zijnde belangen hebben een 'objectieve dimensie'. Dat een slachtoffer de aan hem toegebrachte schade niet als zodanig ervaart of erkent, of van oordeel is dat er juist wel sprake is van schade, is voor de aanwezigheid van schade niet van doorslaggevend belang. De subsidiariteitseis vereist een nauwgezette afweging of bepaald gedrag wel of niet strafbaar moet worden gesteld. Het kan daarbij gaan om een afweging van soms strijdige belangen. De subsidiariteitseis wordt ook gebruikt om andere argumenten te betrekken dan materieelrechtelijke; een vraag kan zijn of handhaving door middel van het strafrecht wel het meest geëigend is. Wanneer daarbij niet de inzet van politie en justitie (maar van een bestuursorgaan) wordt beoogd, of wanneer in plaats van een vrijheidsstraf een geldboete als maximumstraf wordt overwogen, kan de vraag zijn of strafbaarstelling voor de hand ligt.

\section{Voorfase van schade}

Schade wordt uitgelegd in termen van resultaat; er is een terugslag in belangen opgetreden. Denkbaar is dat een gedraging nog geen terugslag heeft teweeggebracht, maar wel een kans daarop aanwezig is. Er is dan gevaar voor schade. Tegenwoordig wordt in de literatuur onderschreven dat ook gevaar voor schade onder het bereik van de strafwet mag vallen. ${ }^{26}$ Daarbij kunnen we onderscheid maken tussen gedragingen die een objectief aanmerkelijke kans op schade opleveren en dus dicht bij schade zijn gelegen en gedragingen waarvan niet kan worden gezegd dat zij een aanmerkelijke kans op schade opleveren, omdat voor het intreden van schade nog meer gedragingen nodig zijn. In beide gevallen kunnen we spreken van concrete gevaarzettingsdelicten, omdat de aard van de in te treden schade duidelijk is. Het verschil tussen beide gevaarzettingsdelicten ligt in de kans op schade. Die kans is in het eerste geval ten minste aanmerkelijk, in het tweede geval is die kans niet goed te bepalen en dus onzeker, want verder van het gevolg gelegen. ${ }^{27}$ We zouden kunnen zeggen dat ook bij een grotere onzekerheid omtrent het intreden van het gevolg sprake is van gevaar voor schade. Dat oordeel wordt bij grote onzekerheid afhankelijker van andere factoren dan de kans dat het gevolg (de schade) intreedt. Als factoren worden genoemd de belangen die op het spel staan, de mogelijke slachtoffers en de waarde van de gevaarzettende handeling. ${ }^{28}$

Zie met verdere verwijzingen J.M. ten Voorde, 'Aanzetten tot criteria voor strafbaarstelling in de voorfase,' in Criteria voor strafbaarstelling in een nieuwe dynamiek. Symbolische legitimiteit versus maatschappelijke en sociaalwetenschappelijke realiteit, red. C.P.M. Cleiren e.a. (Den Haag: Boom Lemma, 2012), 65-85.

27 Het concrete gevaar dat ver van de in te treden schade ligt, zouden we abstract gevaar kunnen noemen, niet omdat de schade onduidelijk is, maar omdat de onzekerheidsmarge dat schade intreedt groter is.

28 Simester en Von Hirsch, Crimes, Harms, and Wrongs, 55. 
Bij strafbaarstelling van gedrag kunnen verschillende belangen met elkaar botsen. In het geval van seksuele communicatie met minderjarigen botsen de vrijheid van meningsuiting met de bescherming van kinderen om zich (seksueel) te ontplooien. Beide rechten zijn van belang. Een zorgvuldige afweging van deze rechten is dan gewenst, waarbij de aard, inhoud en indringendheid van de meningsuiting moeten worden afgewogen tegenover de kwetsbaarheid van de persoon waarmee over seks wordt gecommuniceerd. Hoe kwetsbaarder deze persoon, gelet op zijn leeftijd, hulpbehoevendheid of afhankelijkheid ten opzichte van de andere persoon, hoe eerder strafbaarstelling van seksuele communicatie voor de hand ligt. Niet altijd zal het de vrijheid van meningsuiting zijn waartegen de bescherming van kinderen moet worden afgewogen. Door bepaalde uitingen kunnen ook andere belangen dan de vrijheid van meningsuiting naar voren komen. Soms kan het wenselijk zijn dat bepaalde uitingen worden gedaan, bijvoorbeeld in het kader van opvoeding, scholing en misschien zelfs kunst, om gesprekken over de uitingen te kunnen voeren. Ouders en onderwijzers moeten bepaalde onderwerpen kunnen bespreken, bijvoorbeeld omdat een gesprek over die onderwerpen het kind kan helpen bij diens (seksuele) ontwikkeling. De vraag of dergelijke gesprekken strafbaar moeten worden gesteld is dan geen afweging tussen de bescherming van het kind en de vrijheid van meningsuiting, maar tussen bescherming en het belang van opvoeding.

In hoeverre deze factoren mogen bijdragen aan de vraag of strafbaarstelling aanvaardbaar is, wordt verder bepaald aan de hand van argumenten die betrekking hebben op de persoon van de dader en argumenten die betrekking hebben op de aard van de gedraging. Met betrekking tot de eerste argumenten wordt in literatuur opgemerkt dat de vraag naar strafbaarstelling kan worden gekoppeld aan algemene of contextspecifieke zorgplichten van burgers in een rechtsgemeenschap. ${ }^{29}$ Hoe groter de zorgplicht is, hoe eerder de gevaarzettende handeling strafbaar mag worden gesteld (ook bij een feitelijk geringe kans op schade). Hierbij moet worden opgemerkt dat een al te grote nadruk op burgerschapseisen zich slecht verhoudt tot het liberale uitgangspunt van het schadebeginsel dat aan burgerschap weinig inhoudelijke eisen stelt. ${ }^{30}$ Met betrekking tot de aard van de gedraging wordt in literatuur gewezen op aan het schadeveroorzakend handelen voorafgaande deelneming tussen twee of meer personen, zoals uitlokking en voorbereidende medeplichtigheid waarbij de persoon het door een ander te plegen schadeveroorzakende feit opzettelijk bevordert of vergemakkelijkt. Bevordering of vergemakkelijking kan in termen van effectiviteit worden uitgelegd. Hoe effectiever het bieden van hulp is voor het te bereiken resultaat, hoe eerder strafbaarstelling van het bieden van die hulp voor de hand ligt. Aangenomen zou kunnen worden deze voorwaarde ook toe te passen is in het geval iemand eigen misdrijf beoogt te bevorderen. ${ }^{31}$ Dan wordt strafbaarheid niet bepaald vanwege de

29 Jeroen ten Voorde, 'Prohibiting Remote Harms. On Endangerment, Citizenship and Control,' Utrecht Law Review (2014): 163-79.

30 Herman R. van Gunsteren, A Theory of Citizenship: Organizing Plurality in Contemporary Democracies (Boulder, CO/Oxford: Westview Press, 1998), 17.

31 Simester en Von Hirsch, Crimes, Harms, and Wrongs, 81. 
deelneming voorafgaand aan het misdrijf, maar gelet op de effectiviteit van de gedragingen in het licht van het beoogde misdrijf. De effectiviteitsvoorwaarde is niet de enig denkbare voorwaarde, al past zij goed bij het schadebeginsel dat waarde hecht aan het feitelijke onderdeel van schade. Aangezien het schadebeginsel mede bestaat uit een normatief onderdeel, verbaast het niet dat naast de effectiviteitsvoorwaarde ook andere voorwaarden van belang kunnen zijn voor strafbaarstelling, waaronder - tot op zekere hoogte - de zojuist genoemde zorgplichten.

\section{Virtuele grooming en schade}

Communicatie over seks: schade aan minderjarigen?

Bij grooming gaat het primair om communicatie tussen personen (ook wel sexting genoemd). Onder communicatie versta ik het voeren van gesprekken tussen twee of meer personen. Communicatie met behulp van beelden laat ik hier buiten beschouwing. Met communicatie wordt door de groomer een bepaald doel beoogd, namelijk het in contact komen met een minderjarige teneinde deze ertoe te brengen hem te ontmoeten en vervolgens seksuele gedragingen te verrichten met (zichzelf of met) de groomer. ${ }^{32}$ Is dergelijke communicatie met kinderen op zichzelf schadelijk?

Met betrekking tot meerderjarigen kan wellicht worden aangenomen dat een gesprek over seks door de ontvanger wordt ervaren als onaangenaam en dat het hem enige tijd last bezorgt. Minder voor de hand ligt het te stellen dat een onaangenaam gesprek bij de volwassen ontvanger ertoe leidt dat deze geen goed leven meer kan leiden. ${ }^{33}$ Daarvoor kan een gesprek tamelijk vluchtig en de precieze inhoud relatief snel vergeten zijn. ${ }^{34}$ Dat geldt wellicht nog meer voor gesprekken die op internet plaatsvinden, ook gelet op de anonimiteit van de gesprekspartners. Van eenmalige, kortdurende gesprekken die geen zeer schokkende inhoud hebben of een concrete bedreiging met een strafbaar feit inhouden kan niet worden volgehouden dat zij het goede leven zodanig aantasten dat sprake is van schade. Feitelijke schade lijkt dus te ontbreken. Die conclusie vindt steun in het

32 De wetgever overweegt om ook de enkele communicatie met minderjarigen strafbaar te stellen (Kamerstukken II 2015/16, 29279, 300). Op de rechtvaardiging van strafbaarstelling van deze zgn. sexting of sexchatting wordt in deze bijdrage niet verder ingegaan.

33 Vgl. Simester en Von Hirsch, Crimes, Harms, and Wrongs, 109.

34 Dat neemt niet weg dat 'sexchatting' wel verslavend kan zijn: Michelle Drouin en Daniel A. Miller, 'Online Erotica Usage as a Mediator between Internet Addiction and Engagement in Risky Online Sexual Behaviors,' Cyberpsychology: Journal of Psychosocial Research on Cyberspace (2016): art. 2. 
feit dat veel mensen nogal wat van dergelijke seksuele gesprekken voeren, ${ }^{35}$ zonder daar problemen mee te hebben. ${ }^{36}$

Voor schade is ook nodig aantasting van objectieve rechten. Strafbaarstelling van seksuele delicten met minderjarigen wordt in het bijzonder gerechtvaardigd door het belang dat minderjarigen 'in een veilige omgeving [kunnen] opgroeien en zich op gezonde en evenwichtige wijze kunnen ontwikkelen tot volwassenen'. ${ }^{37}$ Onder die ontwikkeling wordt de seksuele ontwikkeling van minderjarigen begrepen. Vanaf een bepaalde leeftijd, volgens artikel 248e Sr vanaf 16 jaar, moeten minderjarigen zelf kunnen bepalen wanneer en op welke wijze zij met wie over seks willen communiceren. ${ }^{38}$ Bescherming en zelfontplooiing van kinderen staan centraal, niet alleen als op zichzelf staande belangen, maar ook als op elkaar betrokken belangen. Zelfontplooiing moet kunnen geschieden in een beschermde omgeving.

Strafbaarstelling van seksuele delicten waarbij minderjarigen slachtoffer zijn, denk bijvoorbeeld aan ontucht (art. 247 Sr), vraagt vanwege de kwetsbaarheid van kinderen en de noodzaak dat zij zich in een beschermde omgeving moeten kunnen ontwikkelen om een actief optredende strafrechtelijke overheid. Kinderen kunnen zich minder goed tegen gedragingen van anderen verweren, terwijl de gevolgen van gedragingen van anderen de algemene ontwikkeling van minderjarigen blijvend en in ernstige mate kan belemmeren. Dat die belemmering niet op korte termijn zichtbaar is of zich zelfs eerst op latere leeftijd manifesteert, is een omstandigheid die in het kader van strafbaarstelling niet moet worden gebagatelliseerd. De feitelijke en normatieve component van schade hoeven bij seksueel misbruik van kinderen niet op het hetzelfde moment in te treden. Waar de normatieve component van schade ten tijde van de (ontuchtige) handeling aanwezig kan zijn, kan de feitelijke component zich bij een persoon op een later moment realiseren. Indien de kans daarop aanmerkelijk is, ${ }^{39}$ zelfs na het passeren van een groot aantal jaren, is de vraag of het ontbreken van schade direct na de handeling aan strafbaarstelling in de weg moet staan. Leidt dat niet tot het bagatelliseren of zelfs ontkennen van de rechtsbelangen die ook op het moment van de gedragingen moeten worden beschermd? Betekent dit dat strafbaarstelling dan wordt gerechtvaardigd omdat het ten tijde van de gedragingen ontbreken van feitelijke

35 Zie onder andere Jose R. Agustina en Esperanza L. Gómez-Durán, 'Sexting: Research Criteria of a Globalized Social Phenomenon,' Archives of Sexual Behavior (2012): 1325-28.

36 Vgl. Carianne Blyth en Lynne D. Roberts, 'Public Attitudes towards Penalties for Sexting by Minors,' Current Issues in Criminal Justice (2014): 143-58; Yolanda Rodríguez-Castro e.a., 'Spanish Adolescents' Attitudes towards Sexting: Validation of a Scale,' Computers in Human Behavior (2017): 375-84.

37 Kamerstukken II 2008/09, 31808 (R1872), 3, 1.

38 Vgl. Alisdair A. Gillespie, 'Adolescents, Sexting, and Human Rights,' Human Rights Law Review (2013): 623-43.

39 Zie t.a.v. seksueel misbruik van minderjarigen Elizabeth Oddone Paolucci, Mark L. Genuis en Claudio Violato, 'A Meta-Analysis of Published Research on the Effects of Child Sexual Abuse,' The Journal of Psychology (2001): 17-36. Zie ook Helen C. Whittle, Chatherine Hamilton-Giachritsis en Anthony R. Beech, 'Victim's Voices: The Impact of Online Grooming and Sexual Abuse,' Universal Journal of Psychology (2013): 59-71. 
schade door normatieve schade wordt gecompenseerd? Ik meen dat dit niet het geval is; de compensatie bestaat in de aanmerkelijke kans op het op latere leeftijd intreden van feitelijke schade. Ook in dat geval liggen aan strafbaarstelling feitelijke en normatieve schade ten grondslag.

Uit de omschrijving van het feitelijke onderdeel van schade kan, voor zover het om communicatie gaat, worden afgeleid dat van meerderjarigen mag worden verlangd dat zij zich sommige uitingen laten welgevallen en niet te snel aannemen dat hun leven door bepaalde uitingen in ernstige mate is ontregeld. Dat uitgangspunt kan voor juist worden aangenomen als het gaat om meerderjarigen. ${ }^{40}$ Ten aanzien van minderjarigen hangt het oordeel af van de omstandigheden waaronder de gesprekken werden gevoerd en de leeftijd (en psychische kwetsbaarheid) van de minderjarige ten tijde van de gesprekken. Hoe jonger de minderjarige op dat moment of die momenten was, hoe minder goed zij de reikwijdte van een uitlating kan inschatten, ${ }^{41}$ terwijl ook het besef welke uitlatingen men zich in gesprekken met anderen al dan niet moet laten welgevallen nog in ontwikkeling is. Dit gebrek aan besef vormt een argument om schade aan te nemen. We zouden kunnen stellen dat minderjarigen nog geen zelfbescherming hebben ontwikkeld. $\mathrm{Zij}$ moeten worden geholpen een dikke huid te ontwikkelen. Zonder het hebben daarvan als meerderjarige is het leiden van een goed leven in een open, pluriforme samenleving met een veelheid aan conflicterende opvattingen over het goede leven niet goed mogelijk. Het ontwikkelen van een dikke huid moet echter in een zo veilig mogelijke omgeving plaatsvinden. Wanneer minderjarigen al op jonge leeftijd worden blootgesteld aan gedrag waartegen zij zich pas als meerderjarigen worden geacht te kunnen verzetten, in een omgeving die met de belangen van minderjarigen geen rekening houdt, zou kunnen worden aangenomen dat de ontwikkeling van het afweermechanisme die zij als meerderjarigen nodig hebben wordt belemmerd. Het belemmeren daarvan zou als feitelijke schade kunnen worden aangeduid. ${ }^{42}$ Dat het online contact met minderjarigen zich kenmerkt door vluchtigheid en anonimiteit maakt dat oordeel niet meteen anders. Er zou zelfs kunnen worden gesteld dat een vluchtig of anoniem maar opdringerig en indringend gesprek over seks het ontwikkelen van een afweermechanisme bemoeilijkt, omdat het gesprek niet op waarde kan worden geschat en niet kan bijdragen aan het ontwikkelen van goede oordeelsvorming over hetgeen de ene persoon tegen een andere persoon over seks mag zeggen. Van een voortdurend of vaker plaatsvindend gesprek over seks, waarbij de gespreksdeelnemer zich wel (met een valse naam) of niet kenbaar maakt, kan eveneens worden gesproken van schade, in

40 Simester en Von Hirsch, Crimes, Harms, and Wrongs, 113.

41 Vgl. Irene R. Berson, 'Grooming Cybervictims,' Journal of School Violence (2003): 8.

42 Hoe ouder de minderjarige, hoe minder het argument opgaat. Hoe langer de nadruk op bescherming wordt gelegd, hoe sneller kinderen zullen experimenteren, hoe eerder een te weinig gedifferentieerde strafbaarstelling tot schade aan die kinderen zal leiden. Vgl. Murray Lee e.a., "Let's Get Sexting”: Risk, Power, Sex and Criminalisation in the Moral Domain,' International Journal for Crime and Justice (2013): 35-49. Dat wordt wellicht anders wanneer de kwetsbaarheid van het kind ook wordt verklaard door de stand van zijn psychosociale ontwikkeling ten tijde van de met hem gevoerde gesprekken. 
ieder geval wanneer dat gesprek het langzaam inkapselen en het zogeheten 'seksueel gereed maken' van de minderjarige inhoudt. Ook tegen dergelijke meer subtiele vormen van communicatie kunnen (jonge) kinderen zich in het algemeen nog niet goed verweren en ook dergelijke gesprekken kunnen aan de ontwikkeling van zelfbescherming in de weg staan.

Een tweede argument om van schade te spreken zou als volgt kunnen luiden. Gesprekken tussen een minderjarige en een meerderjarige die het kind verleidt, aanmoedigt of chanteert kan de minderjarige ontmoedigen om zich opnieuw op internet te begeven en met anderen te communiceren. In dat geval wordt het kind geraakt in zijn belangen. Internet is een belangrijk en waardevol publiek medium om kennis te vergaren, contacten te leggen, enzovoorts, hetgeen in deze tijd van groot belang is voor persoonlijke ontwikkeling. Door geen gebruik meer te willen of te kunnen maken van dit medium, terwijl veel sociaal verkeer onder jongeren zich via sociale media afspeelt, zou een vooruitzicht op schade ('reactive harm') kunnen ontstaan. ${ }^{43}$ Tegelijkertijd is het niet vanzelfsprekend dat het zich niet meer kunnen begeven op de chatsite waar het kind een vervelende ervaring heeft opgedaan, feitelijke schade oplevert, of dat de kans daarop aanmerkelijk is in de nabije of verdere toekomst. Er zijn immers alternatieven voorhanden, terwijl kinderen leren persoonlijke informatie af te schermen en selectiever te zijn in het leggen en onderhouden van online contacten. ${ }^{44}$ In zoverre zou het betrachten van een grotere voorzichtigheid of terughoudendheid in het chatten ook kunnen helpen bij de ontwikkeling van het kind, zolang het meer wordt vrijgelaten naarmate het kind ouder wordt. De 'wrong' die aan dit argument ten grondslag ligt, zo daarvan kan worden gesproken, overtuigt niet.

\section{Virtuele grooming: gevaar voor schade?}

Nemen we aan dat communicatie over seks onder omstandigheden schadelijk is, wat valt dan over virtuele grooming te zeggen? Virtuele grooming leidt niet tot schade aan de virtuele persoon. Om te beginnen moet dan vaststaan dat virtuele grooming schade aan andere personen teweegbrengt of kan brengen. Daarvoor is nodig is dat de gedraging gevolgen heeft gehad of tot nadeel heeft geleid voor een specifieke persoon of personen. Bij virtuele grooming is daarvan geen sprake. De ander is een computerprogramma waarachter soms een volwassen persoon schuilgaat. Seksuele communicatie met een andere volwassen persoon is om in de 
vorige paragraaf genoemde redenen voor die persoon niet zonder meer schadelijk (hoe vervelend dat gesprek ook voor een volwassene moge zijn). ${ }^{45}$

Een aanmerkelijke kans op schade is er bij virtuele grooming evenmin, omdat het voorstel voor een ontmoeting zich nooit in een ontmoeting met die persoon kan verwezenlijken. ${ }^{46}$ De vraag is of de omstandigheid dat de persoon dacht dat hij met een minderjarige te maken had en het doel had de minderjarige te verleiden tot een ontmoeting tijdens welke hij het slachtoffer zal misbruiken, daaraan iets afdoet. Hoeveel gewicht kan aan het opzet worden gegeven voor het rechtvaardigen van een strafbaarstelling, ook wanneer feitelijke schade niet kan worden gerealiseerd? Over schuld als criterium voor strafbaarstelling bestaan uiteenlopende opvattingen. Als leerstuk speelt het als zodanig geen rol, ${ }^{47}$ wel het aan schuld ten grondslag liggende uitgangspunt, namelijk dat alleen een persoon die in vrijheid voor zijn handelen kon kiezen strafbaar kan zijn. Gedrag dat nooit in vrijheid kan worden begaan, kan niet strafbaar worden gesteld. In zoverre is schuld een criterium voor strafbaarstelling.

Bij virtuele grooming weet de dader, anders dan bij een delict als virtuele kinderporno, niet dat hij niet met een kind communiceert. Hij denkt tijdens het gesprek van doen te hebben met een minderjarige. Dat het kind waarmee de groomer communiceert virtueel is, is wat met de virtuele creatie wordt beoogd; hoe realistischer de reacties van de virtuele creatie tijdens het gesprek, hoe eerder de groomer denkt met een kind te maken te hebben, hoe verder hij wil gaan. Om van grooming te kunnen spreken, is op grond van het geldend recht een gesprek niet voldoende. Ook bij virtuele grooming moet het gaan om het doen van een voorstel voor een ontmoeting en enige handeling om die ontmoeting te realiseren, bijvoorbeeld het verstrekken van een reisschema en een beschrijving naar de plaats van ontmoeting. ${ }^{48}$ De groomer is, wanneer hij niet ontdekt dat hij communiceert met een enkel in de virtuele wereld bestaand kind, niet degene die het beoogde doel niet laat doorgaan. Dat is het virtuele kind dat wellicht kan instemmen met een ontmoeting, maar geen handeling kan verrichten om die ontmoeting (buiten

45 Een vergelijking met virtuele kinderporno of 'verkrachting' van een avatar gaat dan ook niet (helemaal) op. Virtuele kinderporno kan schadelijk zijn wanneer de afbeelding een tekening betreft van een seksuele gedraging van een minderjarige persoon. Zie Suzanne Ost, 'Criminalising Fabricated Images of Child Pornography: A Matter of Harm or Morality?', Legal Studies (2010): 230-56. 'Verkrachting' van een avatar zou schadelijk kunnen zijn voor een persoon wanneer die avatar op deze persoon is gebaseerd. Hierover Jessica Wolfendale, 'My Avatar, My Self: Virtual Harm and Attachment,' Ethics and Information Technology (2007): 111-19. Zie ook Strikwerda, Virtual Acts, Real Crimes?, 45-52. De virtuele persoon die in het kader van virtuele grooming wordt gebruikt, is op niemand in het bijzonder gebaseerd.

46 Denkbaar is dat ooit een ontmoeting wordt gerealiseerd met een virtuele creatie die tijdens de ontmoeting seksuele gedragingen verricht. Ook dan is er geen gevaar voor schade, want achter de virtuele creatie gaat geen minderjarige schuil. Van 'virtuele schade' of 'virtual harm' is dan, anders dan bij virtuele kinderporno in het geval de afbeelding op een kind is gebaseerd, geen sprake.

47 Nina Peršak, Criminalising Harmful Conduct: The Harm Principle, its Limits and Continental Counterparts (New York: Springer, 2007), 79-84.

48 HR 14 mei 2013, ECLI:NL:HR:2013:BZ9941, NJ 2013/296. 
de virtuele wereld) te realiseren. Het is mogelijk dat de groomer van alles doet om zijn doel te laten slagen. Zou het kind niet-virtueel zijn, dan is er gevaar voor schade en de grooming voltooid. Wanneer de groomer met het virtuele kind contact heeft gelegd, is dat een toevallige pech voor de groomer. Moet dergelijk toeval straffeloos blijven? Beantwoording van deze vraag vergt uitwerking van twee verschillende argumenten.

In de eerste plaats kan een vergelijking worden gemaakt met het materieelrechtelijke leerstuk van de absoluut ondeugdelijke poging. Uitgangspunt van dit leerstuk is dat de volstrekte onmogelijkheid om schade te berokkenen niet strafbaar is. ${ }^{49}$ Dan zou kunnen worden beweerd dat virtuele grooming niet strafbaar kan zijn, omdat het slachtoffer nooit seksueel kan worden misbruikt. Wat volstrekt onmogelijk is, is afhankelijk van de uitleg die daaraan wordt gegeven. In een strikte uitleg rekenen we tot absolute ondeugdelijkheid (van het object) de feitelijke onmogelijkheid van het intreden van schade, ongeacht het doel dat werd beoogd. In een vrijere uitleg wordt de handeling mede beoordeeld in het licht van het doel dat werd beoogd. ${ }^{50}$ Een derde uitleg houdt in dat naast de gevaarlijkheid van de handelingen, ook inzicht in de gevaarlijkheid van de dader en diens voornemen argumenten vormen voor strafbaarstelling. De laatste twee opvattingen erkennen voor strafbaarstelling het belang van het doel dat de dader met zijn handelingen beoogt. Dat belang zou kunnen worden vertaald in één of meerdere zorgplichten. Hoe meer een persoon de plicht heeft zich in een bepaalde context aan normen te houden, hoe gevaarlijker zijn handelen is wanneer blijkt dat een persoon zich daaraan in die context niet gehouden heeft. Hoe eerder in dat geval strafbaarstelling in de rede ligt. Deze opvattingen verschillen van de eerste ook in de aard van het gevaar van de handelingen. In de eerste opvattingen moeten de handelingen een concreet gevaar voor schade opleveren. Dat is in de laatste twee opvattingen niet nodig; een bezien vanuit de handelingen abstract gevaar voor schade volstaat voor strafbaarstelling.

Bij virtuele grooming zou het er dan op aankomen te bepalen of de gedraging, ook in het licht van het opzet van de dader, zo ondoeltreffend of ongerijmd is dat seksueel misbruik nooit kan worden gerealiseerd. De ongerijmdheid van de gedraging wordt niet alleen bepaald door de handelingen zelf, maar ook het doel dat de dader met die handelingen beoogt. Ten aanzien van de ongerijmdheid van de handelingen kunnen de aard en inhoud van de gesprekken relevant zijn. Kortdurende gesprekken waarin slechts sprake is van toespelingen op seks, zonder dat zij ooit concreet worden, kunnen zo ongerijmd zijn dat zij niet strafbaar moeten worden gesteld. Gesprekken met een concrete inhoud, zoals een voorstel tot een ontmoeting waarbij voor iedereen duidelijk is wat er tijdens die ontmoeting zal plaatsvinden, zullen minder snel ongerijmd zijn, ook in het geval het kind waarmee wordt gecommuniceerd een virtuele creatie is. Kunnen zorgplichten ondersteuning bieden aan het voorstel om dergelijke gesprekken strafbaar te stellen? Ter onderbou-

50 G. Knigge en H.D. Wolswijk, Het materiële strafrecht (Deventer: Wolters Kluwer, 2015), 229. 
wing van een positief antwoord daarop, zou kunnen worden gesteld dat een willekeurige volwassen persoon die op een chatsite een kind benadert, de nodige voorzichtigheid moet betrachten tijdens het voeren van gesprekken en zich ervan moet onthouden over seks te praten. In het geval deze persoon zich tot kinderen voelt aangetrokken, zou van hem extra terughoudendheid mogen worden verlangd. Hij zou zich moeten onthouden van elke benadering van kinderen op chatsites en zich bewust moeten zijn van zijn geaardheid en de consequenties die deze met zich kan meebrengen met betrekking tot de inhoud van gesprekken die hij met kinderen op chatsites zou kunnen voeren. Een dergelijke redenering komt neer op een verzekering dat we kinderen met rust laten en dat we onszelf van die verzekering uitsluiten omdat we weten dat als we met kinderen communiceren we het niet over seks zullen hebben. Volgens Duff is de laatste claim problematisch, omdat we onszelf in dat geval boven onze medeburgers stellen terwijl de erkenning van burgerschap mensen zou moeten motiveren het recht te aanvaarden, ook in die gevallen waarin de mens die wetten voor zichzelf overbodig acht. ${ }^{51}$ Medeburgerschap levert volgens Duff een grond voor strafbaarstelling op. In het kader van onderhavige strafbaarstelling, komt mij dat argument problematisch voor, want aan de erkenning van medeburgerschap kan een bepaalde eis aan onze seksuele geaardheid als burger verbonden worden. Die geaardheid zou zelfs zo belangrijk kunnen worden dat elke communicatie met een minderjarige strafbaar moet worden gesteld, omdat een persoon met een bepaalde geaardheid in elk gesprek wel over seks zal willen praten, ook al zegt hij van niet, bijvoorbeeld omdat hij zich ondanks zijn geaardheid voldoende kan beheersen. Los van de vraag of hier empirische ondersteuning voor bestaat, verhoudt een dergelijke grondslag voor een strafbaarstelling zich slecht tot de liberale grondslag van het schadebeginsel dat een grote vrijheid voor burgers garandeert en waarin een verbod op een geaardheid niet passend is.

Zouden andere interpretaties van zorgplichten, waarin meer van burgers wordt verwacht, tot een andere conclusie leiden? Dat valt niet bij voorbaat uit te sluiten: op communitarisme gebaseerde zorgplichten verlangen van burgers een zeker conformisme aan bepaalde groepsbelangen. Wanneer tot die belangen wordt gerekend het niet mogen verrichten van seksuele handelingen met kinderen, is strafbaarstelling van gedrag op grond van geaardheid denkbaar. Schade wordt in een dergelijke opvatting 'ethische schade', oftewel schade op grond van de opvatting van een specifieke groep, niet gebaseerd op objectieve opvattingen over het goede leven. Dergelijke schade is in het onderhavige geval geen gevolg van een bewuste handeling, maar van iets waarvoor een persoon niet heeft gekozen. Strafbaarstelling voornamelijk baseren op geaardheid verhoudt zich slecht tot het uitgangspunt dat alleen gedrag waarvoor iemand schuld kan hebben strafbaar kan worden gesteld. Daar komt bij dat onduidelijk is in hoeverre strafbaarstelling in een dergelijk geval ultimum remedium is en in overeenstemming met de eisen van proportionaliteit en subsidiariteit. Strafbaarstelling gebaseerd op 'ethische schade' zou grof gezegd kunnen neerkomen op de botte bijl. 
Dit argument zou kunnen worden genuanceerd omdat het blijft gaan om strafbaarstelling van bepaald gedrag, namelijk het op internet benaderen van kinderen met als doel om die kinderen seksueel te misbruiken en enige handeling ondernemen om die ontmoeting te realiseren. Dat neemt mijn aarzelingen bij een al te grote nadruk op de geaardheid van de dader niet weg. Voorbereidingshandelingen zijn op zichzelf namelijk niet vanzelfsprekend wederrechtelijk. De wederrechtelijkheid van de handelingen wordt mede, en naar mate de afstand tot schade groter wordt steeds sterker, bepaald door het doel dat de dader met de handelingen wil bereiken. Voor strafbaarheid blijft wel noodzakelijk dat dit doel (het opzet) en de handelingen in onderling verband en samenhang moeten worden beoordeeld. ${ }^{52}$ Wanneer geaardheid als argument voor strafbaarstelling wordt toegevoegd, dreigt volgens mij een ontkoppeling van dat onderling verband en samenhang tussen opzet en de handelingen, terwijl dat onontbeerlijk is voor de rechtvaardiging van de strafbaarstelling van voorbereidingshandelingen.

In de tweede plaats zou kunnen worden gesteld dat grooming een repetitief karakter heeft. De groomer is niet iemand die een specifiek slachtoffer uitzoekt (ook omdat op chatsites vaak geen gebruik wordt gemaakt van de eigen naam); hij struint het internet vrij willekeurig af op zoek naar slachtoffers. Als een persoon in gesprek treedt met een groomer, begint het proces van grooming dat op enig moment uitmondt in een voorstel tot een ontmoeting. Gedurende dat proces kan het slachtoffer afhaken, waarna de groomer het met een ander probeert. Niet gezegd is dat een groomer altijd het eindresultaat (seksueel misbruik) wil bereiken, wel is de kans groot dat zijn handelingen telkens daarop zijn gericht. Gelet op het repetitieve karakter zou kunnen worden gesteld dat uit het feit dat hij zonder te weten in contact is getreden met een virtueel kind en dat kind groomt (een voorstel voor een ontmoeting doet en enige handeling onderneemt gericht op het verwezenlijken van die ontmoeting), het gevaar bestaat dat hij dat vaker zal doen. Het gevaarzettende karakter van virtuele grooming is dan niet gelegen in het gevaar voor schade in dat specifieke geval (dat gevaar bestaat in objectieve zin immers niet). Het schuilt in het gevaar voor schade in andere, soortgelijke gevallen. ${ }^{53}$

Het bezwaar tegen het funderen van de strafbaarstelling van virtuele grooming op het repetitieve argument is dat zij uitgaat van de veronderstelling dat elke groomer zijn gedrag zal herhalen. Dat valt op basis van bekende daderkenmerken niet in algemene zin aan te nemen ${ }^{54}$ en zou, wanneer strafbaarheid primair op de persoon van de groomer wordt gebaseerd, tot een intentiestrafrecht leiden waarin de gedraging ondergeschikt wordt. In dat geval dreigt opnieuw dat een bepaalde 
seksuele voorkeur grondslag wordt voor strafbaarheid. ${ }^{55}$ Een seksuele voorkeur is in een liberale samenleving niet strafbaar, nog los van de vraag of strafbaarstelling met de eisen van proportionaliteit en subsidiariteit kan worden verenigd. Dat de seksuele voorkeur van de groomer wellicht (en tot op zekere hoogte) in een concrete strafzaak kan worden gebruikt bij het bepalen van een passende sanctie in een individueel geval, is geen argument om een abstracte regel in de vorm van een wettelijke strafbepaling te funderen. Regels voor aansprakelijkheid in concreto zien op iets anders dan regels voor strafbaarstelling in abstracto.

\section{Strafbaarstelling van virtuele grooming als verkapte opsporingsbevoegdheid}

Een onderwerp dat tot dus ver buiten beschouwing is gelaten, is de procesrechtelijke achtergrond van wijziging van de huidige strafbepaling van artikel 248e Sr. $\mathrm{Na}$ de invoering van artikel 248e Sr ontstond in de rechtspraktijk onduidelijkheid over gevallen waarin een groomer door een meerderjarige of een virtuele creatie was overgehaald om een ontmoeting voor te stellen. In die gevallen werd om twee redenen aangenomen dat de groomer niet kon worden bestraft: het slachtoffer was geen 16-minner en de groomer was uitgelokt om een kind te groomen. Dat laatste is, wanneer de meerderjarige een opsporingsambtenaar blijkt te zijn, een in het (Nederlandse) strafprocesrecht ontoelaatbaar geachte opsporingspraktijk. $^{56}$

Het uitlok- of instigatieverbod kan ten aanzien van grooming om twee redenen worden gerechtvaardigd. Allereerst is het onaanvaardbaar dat de strafrechtelijke overheid actief personen opzettelijk brengt tot het begaan van strafbare feiten, in het geval die personen niet al zelf van plan waren die feiten te begaan. ${ }^{57}$ Tevens is het ondenkbaar om kinderen te gebruiken als uitlokkingsmiddel. Dat laatste zou een reden kunnen zijn om het gebruik van virtuele kinderen om groomers op te sporen toe te laten (en virtuele grooming dus strafbaar te stellen); waar het niet ethisch is kinderen als middel te gebruiken, is dat bij virtuele kinderen geen probleem. Het eerste argument wordt daarmee echter niet weggenomen.

Het instigatieverbod blijft ook met de nieuwe strafbaarstelling gehandhaafd. De gewijzigde omschrijving van artikel 248e Sr stelt ook strafbaar het benaderen van andere personen dan 16-minners, wanneer het doel van de groomer is een ontmoeting voor te stellen met een 16-minner met als doel hem seksueel te misbruiken of daarvan kinderporno te maken en enige handeling te verrichten om een ontmoeting te verwezenlijken. Het initiatief moet volgens de wetgever blijven uitgaan van de groomer. ${ }^{58}$ Opvallend is dat de staatssecretaris onderkent dat bij het

55 Vgl. Ost, 'Criminalising Fabricated,' 161; Marie Eneman, Alisdair A. Gillespie en Bernd Stahl, 'Criminalising Fantasies: The Regulation of Virtual Child Pornography,' in Proceedings of the 17th European Conference on Information Systems (2009).

56 Smeets, 'De "lokpuber": een mislukt experiment.'

57 B.F. Keulen en G. Knigge, Ons Strafrecht. Strafprocesrecht (Deventer: Kluwer, 2016), 344-45.

58 Kamerstukken II 2016/17, 34372, 6, 115; Handelingen II 13 december 2016, 34-26-48. 
gebruik van een virtuele creatie uitlokking 'onvermijdelijk' is. ${ }^{59}$ Dit feitelijke oordeel, dat hij baseert op ervaringen uit de rechtspraktijk, kan niet tot het normatieve oordeel leiden dat de nieuwe strafbaarstelling het instigatieverbod op toelaatbare wijze omzeilt en dus kan worden aanvaard. Dat iets onvermijdelijk is, kan op zichzelf geen argument vormen een verbod te omzeilen. De vraag is echter of hier van omzeilen van een verbod kan worden gesproken. Dat hangt af van de precieze uitleg van het instigatieverbod.

In de eerste plaats geldt het instigatieverbod slechts voor overheidsdienaren; zolang zij geen bemoeienis hebben met het gebruik van een virtuele creatie in de aanpak van grooming, ligt - wanneer een burger een andere burger ergens toe aanzet - het aanspreken van de overheid wellicht minder voor de hand. Dit argument is minder sterk geworden, nu de overheid met het opnemen van de term 'virtuele creatie' in de wet het vermoeden op zich kan laden bemoeienis te hebben met de opsporing van grooming met behulp van virtuele creaties. In de tweede plaats kan het instigatieverbod op twee manieren worden ingevuld: objectief of subjectief. Bij een objectieve benadering ligt de nadruk meer op de handelwijze van opsporingsambtenaren, terwijl bij een subjectieve benadering het al aanwezige opzet van de persoon centraal staat. In een objectieve benadering is elk opzettelijk uitlokken niet toegestaan. Bij een subjectieve benadering is pas dan sprake van schending van het instigatieverbod wanneer verdachtes opzet is ontstaan ten gevolge van de uitlokking. Uitlokkende handelingen van de virtuele creatie kunnen in de subjectieve benadering worden aanvaard, mits uit de gedragingen van de verdachte reeds de intentie om te groomen blijkt. De rechtspraak van het Europees Hof voor de Rechten van de Mens sluit een subjectieve benadering van het instigatieverbod niet uit. ${ }^{60}$ Dat leidt er wellicht toe dat het instigatieverbod minder strikt is dan op het eerste gezicht zou kunnen worden gedacht, zodat niet alle vormen van uitlokking door een virtuele creatie zonder meer ontoelaatbaar zijn. Dit genuanceerde oordeel ziet echter alleen op het gebruik van een virtuele creatie ten behoeve van de opsporing. Het komt mij minder gelukkig voor dit oordeel als argument te gebruiken vóór strafbaarstelling van virtuele grooming, omdat het afleidt van de met de voorgestelde strafbaarstelling gesignaleerde inhoudelijke problemen.

\section{Slotopmerkingen}

In deze bijdrage stond de strafbaarstelling van virtuele grooming centraal. Onderzocht werd of zij op basis van het schadebeginsel kan worden gerechtvaardigd. Voor het schadebeginsel werd gekozen, omdat de wetgever dit beginsel gebruikt ter rechtvaardiging van de nieuwe strafbaarstelling. In deze bijdrage is onderzocht of de strafbaarstelling op schade of gevaar voor schade kan worden gebaseerd. Het ligt niet voor de hand bij virtuele grooming te spreken van schade. Ook van een concreet gevaar voor schade lijkt geen sprake te zijn. Dat zou anders kun-

60 Keulen en Knigge, Ons Strafrecht. Strafprocesrecht, 344-45. 
nen liggen wanneer communicatie met kinderen schadelijk is. Dan zou kunnen worden volgehouden dat virtuele grooming een gevaar voor schade oplevert. Niet valt uit te sluiten dat communicatie over seks inderdaad schade aan kinderen toebrengt, in het bijzonder wanneer wordt aangenomen dat het worden blootgesteld aan seks en porno afbreuk doet aan het ontwikkelen van een afweermechanisme die mensen als volwassene nodig hebben om zich in een open, pluriforme samenleving staande te houden. Indien we aannemen dat grooming met kinderen schadelijk is, ontstaat er ruimte om virtuele grooming te beschouwen als gevaar voor schade. Het gaat dan om een abstract gevaar voor schade, aangezien het gevaar bij virtuele grooming niet bij niet-virtuele kinderen kan worden gerealiseerd. Het gevaar is slechts indirect op deze kinderen gericht. Dat betekent echter niet dat dit gedrag zonder meer strafbaar zou moeten worden gesteld. Het probleem is dat de schade nooit kan intreden; zij kan slechts intreden wanneer wordt aangenomen dat de groomer zijn gedrag zal herhalen en er geen sprake is van absolute ondeugdelijkheid. Hoewel we niet te veel waarde moeten hechten aan absolute ondeugdelijkheid, nemen we aan dat sommige handelingen niet strafwaardig zijn, zelfs al is er sprake van een misdadig doel. In beide gevallen bestaat de kans dat de strafbaarstelling in belangrijke mate wordt opgehangen aan de persoon van de dader. Dat brengt het gevaar van strafbaarstelling van tamelijke onproblematische handelingen met zich en een al te grote nadruk op het opzet van de dader, afgeleid uit een bepaalde geaardheid.

De persoonlijkheid van de dader kan weliswaar worden gebruikt in een strafzaak in concreto, bij het vormgeven van een strafbaarstelling in abstracto kan dit argument geen rol spelen.

De Nederlandse wetgever heeft zich om rechtvaardiging van de strafbaarstelling nauwelijks bekommerd (hij ziet virtuele grooming primair als opsporingsmethode, niet als strafbaarstelling). De geformuleerde argumenten rechtvaardigen de voorgestelde strafbaarstelling niet. Dat voorbereidingsdelicten vooral bedoeld zijn de opsporing te faciliteren, ${ }^{61}$ ontslaat de wetgever niet de strafbaarstelling ook zelf van een rechtvaardiging te voorzien, gebaseerd op uitgangspunten die daarvoor zouden moeten gelden.

61 G.P.M.F. Mols, 'Over de opmars van de strafbare voorbereiding (afscheidsrede Universiteit Maastricht),' Nieuwsbrief Strafrecht (2016): 8. 